\title{
Exceeding the permissible noise levels from rail transport in the Kysuce region
}

\author{
Alžbeta Pultznerová ${ }^{*}$ and Martin Mečár ${ }^{1}$ \\ ${ }^{1}$ University of Žilina, Faculty of Civil Engineering, Univerzitná 8215/1, 01026 Žilina, Slovak \\ Republic
}

\begin{abstract}
Rail transport is a source of noise that has disturbing effects on the environment. Adverse noise emissions must be observed and at the same time keep the permissible noise levels that depend on the type of protected area given by the Slovak legislation. The paper deals with compliance and analysis of these permitted noise values in some selected locations of the railway line in the Kysuce region.
\end{abstract}

\section{Introduction}

Noise emissions represent a significant environmental burden on the environment. The largest polluters include transport.

Although the railway noise is considered to be less burdensome it is the second most dominant source of the environmental noise in Europe with nearly 7 million people exposed to levels above $55 \mathrm{~dB} \mathrm{~L}_{\mathrm{den}}$ in 2012 considering people exposed in urban areas. [1]

The topography of the terrain, its absorption properties and obstacles on the way of spreading from the source, for spreading noise in the external environment is very important. The range and intensity of noise is also influenced by the substance through which it spreads. In the case of the spread of noise from railway transport in outside, it is air and its climatic conditions. However, the climatic factors are not considered in the paper and it will only deal with the spread of noise from rail traffic in the free space in the Kysuce region and its reduction, depending on the distance from the source.

\section{2 permissible noise limits in transport}

Unlike to road traffic, where permissible noise limits at the source have existed in the EU since the 1970s, noise standards for trains only came into force at the beginning of the twenty-first century [2]

In 2007, Regulation 549/2007 of the Ministry of Health of the Slovak Republic, in which the permissible values of noise $\mathrm{L}_{\mathrm{Aeq}, \mathrm{p}}$ for rail transport compared to the values defined in Government Regulation 339/2006 have not changed. This decree is still valid and in full wording the permissible limits are given in Tab. 1.

* Corresponding author: alzbeta.pultznerova@,fstav.uniza.sk 
The noise levels are evaluated for the purposes of spatial planning and control at $1.5 \mathrm{~m}$ $\pm 0.2 \mathrm{~m}$ above the ground outside the building or in a front of peripheral wall of a building, the noise are assessed at the distance of $1.5 \mathrm{~m} \pm 0.5 \mathrm{~m}$ of the wall and at $1.5 \mathrm{~m} \pm 0.2 \mathrm{~m}$ above the floor of the relevant floor levels. The Surroundings means the area within $100 \mathrm{~m}$ away from an adjacent axis of driving lane of road or from the axis of the adjacent railroad tracks [3].

Tab. 1 The permissible noise limits defining the parameters of environmental noise [3]

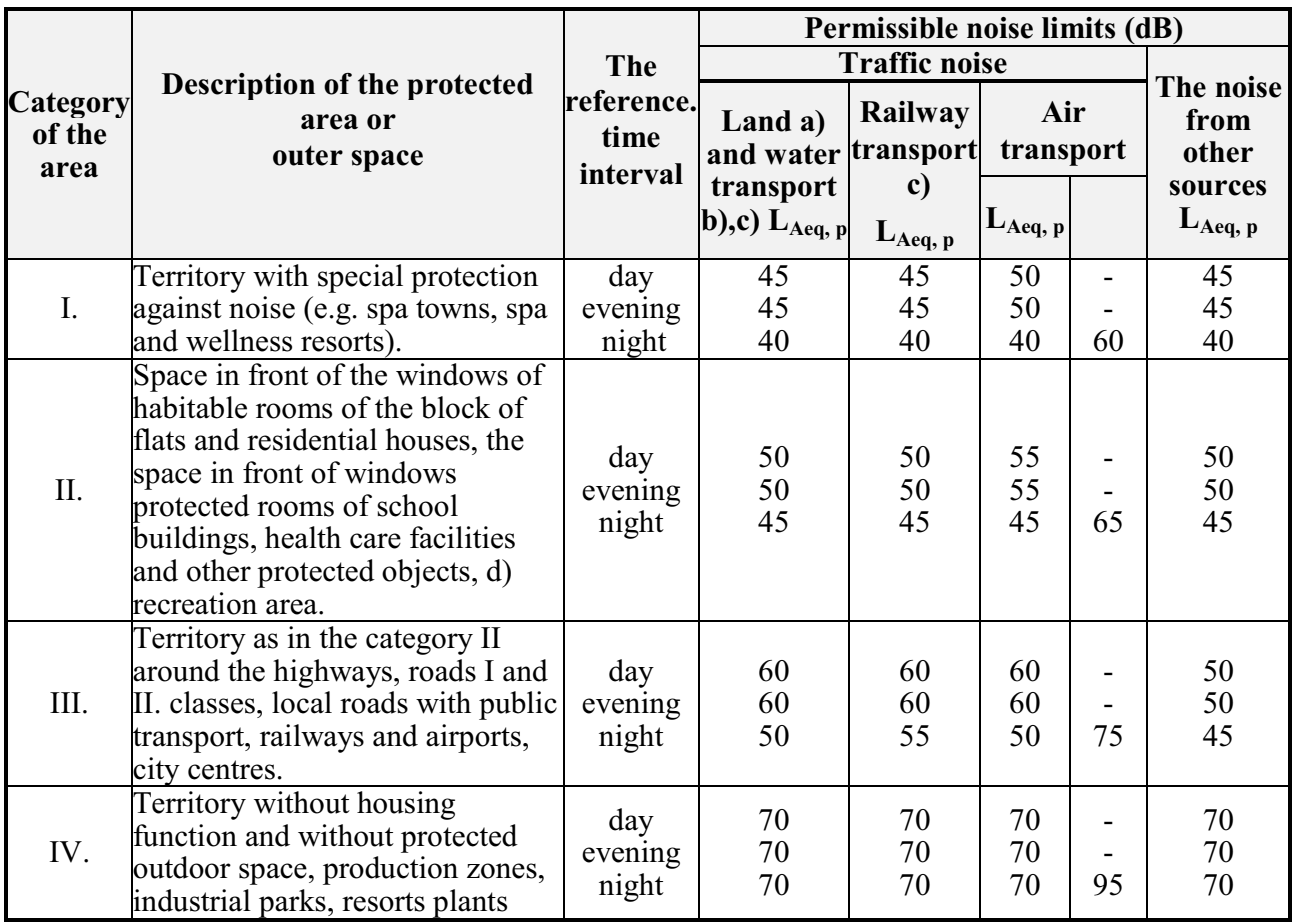

(a) The permissible values apply to the dry road surface and uninterrupted terrain, in the case of seasonal installations, noise shall be assessed under conditions which may be assumed in operation.

(b) Land transport is the transport of roads, including tramway.

(c) Stops for local public transport, bus, rail, waterway and taxi stations for the entry and exit of persons are assessed as part of the land and waterways.

d) The permissible values in front of the non-residential facade are applied at the time of their use, for example schools during classes, etc.

\section{Noise study in the Kysuce region}

Measurements were carried out during the night-time on railway line No. 127 in various places in the village Čadca and Svrčinovec in 10 measuring points according to the valid Regulation.

\subsection{Evaluation of the noise limits compliance}

To evaluate the assessed values for comparison with the limit value under current legislation, the equivalent noise pressure level A - weighted sound pressure level is used. 
Equivalent A - weighted sound pressure level of the continuous sound $\mathrm{L}_{\mathrm{pAeq}}$ - timeaveraged mean A level, which is used to describe the sound with varying levels of sound. It is calculated as the sound pressure that is energetically equivalent to the long-term effects of intermittent noise or noise with varying sound level [4].

The sound pressure level was counted by the formula 1 :

$$
L_{p A e q, T}=10 \cdot \log \left(\frac{1}{T} \cdot \int_{0}^{T} \frac{p_{A}^{2}(t)}{p_{0}^{2}} d t\right)
$$

where:

$T \quad-$ measurement duration, (s),

$p_{0} \quad-\quad$ reference value of sound pressure, $\left(2.10^{-5} \mathrm{~Pa}\right)$,

$p_{A(t)} \quad-$ instantaneous acoustic pressure of the sound signal, $(\mathrm{Pa})$.

The measured $L_{R \text {,Aeq, } n}$ value is measured value $L_{p A e q}$, $T$ increased by uncertainty of measurement $\mathrm{U}$.

Uncertainty of measurement and sound prediction determined according the guidance No: NRÚ / 3116/2005 dated 2.5.2005. Classification of the measured noise, depending on the frequency composition and its directional properties, results in the resulting expanded measurement uncertainty $\mathrm{U}=1.8 \mathrm{~dB}[5]$.

From the particular hour measurements of LAeq, $1 \mathrm{~h}$ noise events, which were not caused by railway operation were "cut out". The particular hourly noise levels were energy calculated by the formula [6]:

$$
L_{\text {Aeq, } p}=10 . \log \left(\frac{1}{T} \sum_{j=1}^{8} 10^{0,1 L_{\text {Aeq }, j}}\right)
$$

where:

$\mathrm{L}_{\text {Aeq,p }}-\quad$ equivalent noise pressure level [dB];

$\mathrm{L}_{\text {Aeq,j }}-\quad$ equivalent noise pressure level measured in one hour intervals $[\mathrm{dB}]$;

$\mathrm{j} \quad-\quad$ number of equivalent noise pressure levels measured during night time;

$\mathrm{T}$ - measurement duration, in our case it is 8 hour (from 22,00 to 6,00). [hour]

\subsection{Assessment of noise study in the Kysuce region}

In-situ measurements of the non- modernised track were used to assess the value compared to the permissible value according to valid legislation, with the measurement points being chosen in the residential area beside of the railway track under consideration

- in category of the area II. - at the distance over $100 \mathrm{~m}$ from the adjacent railway track No. 127 ,

- in category of the area III. - at the distance to $100 \mathrm{~m}$ from the adjacent railway track No. 127.

Tab. 2 Sample of the one hour equivalent noise pressure level measured in point M4 - $2 \mathrm{~m}$ in front of the window of residential room on 2nd floor of house No. 370, by Špindel Street, Čadca town, approximately $39 \mathrm{~m}$ from track No. 127 and $30 \mathrm{~m}$ from the road I/11[7]

\begin{tabular}{|l|c|c|c|c|c|c|c|c|}
\hline Time (h) & $22-23$ & $23-00$ & $00-01$ & $01-02$ & $02-03$ & $03-04$ & $04-05$ & $05-06$ \\
\hline $\mathrm{L}_{\text {Aeq, } \mathrm{lh}}(\mathrm{dB})$ & 63.3 & 63.03 & 62.4 & 66.4 & 66.6 & 68.7 & 67.6 & 67.0 \\
\hline
\end{tabular}




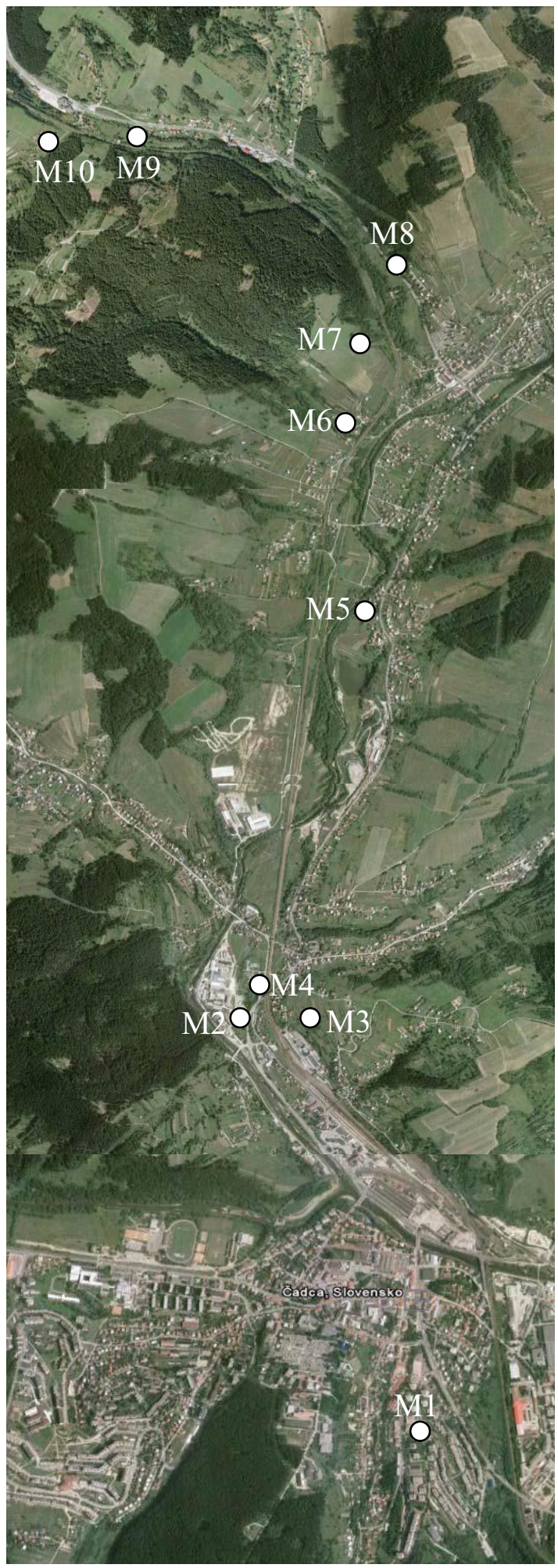

Fig. 1 Measuring points in the Čadca town and Svrčinovec settlement [7] 
List of measuring points - see Fig. 1 [7]:

M1 - $2 \mathrm{~m}$ in front of the window of residential room on $7^{\text {th }}$ of residential house No. 2589

J. Král' street, Čadca town, approximately $145 \mathrm{~m}$ from railway track No. 127, $118 \mathrm{~m}$ from the road I/11 and approximately $15 \mathrm{~m}$ from J. Král' street,

Total equivalent sound pressure level A measured during night time 22:00 - 06:00:

$\mathrm{L}_{\text {Aeq }, 8 \mathrm{~h} \text { night }}=61.5 \mathrm{~dB} \ldots \quad$ overall noise - environment noise,

$\mathrm{L}_{\text {Aeq }, 8 \mathrm{~h} \text { night }}=60.1 \mathrm{~dB} \ldots \quad$ only noise from the railway line No. 127,

M2 - $2 \mathrm{~m}$ in front of the window of residential room on $2^{\text {nd }}$ floor of house No. 297 Slovanská cesta street, Čadca town, approximately $60 \mathrm{~m}$ from railway track No. 127, Total equivalent sound pressure level A measured during night time 22:00 - 06:00:

$\mathrm{L}_{\text {Aeq, } 8 \mathrm{~h} \text { night }}=60.3 \mathrm{~dB} \ldots \quad$ overall noise - environment noise,

$\mathrm{L}_{\text {Aeq, } 8 \mathrm{~h} \text { night }}=59.6 \mathrm{~dB} \ldots \quad$ only noise from the railway line No. 127 ,

M3 - on the fence of the garden of house No.219, Čadca - Drahošanka, altitude from the ground 1,5 m and approximately $300 \mathrm{~m}$ from railway track No. 127,

Total equivalent sound pressure level A measured during night time 22:00 - 06:00:

$\mathrm{L}_{\text {Aeq }, 8 \mathrm{~h} \text { night }}=51.2 \mathrm{~dB} \ldots \quad$ overall noise - environment noise,

$\mathrm{L}_{\text {Aeq }, 8 \mathrm{~h} \text { night }}=48.6 \mathrm{~dB} \ldots \quad$ only noise from the railway line No. 127 ,

M4 - $2 \mathrm{~m}$ in front of the window of residential room on $2^{\text {nd }}$ floor of house No. 370, by Špindel street, Čadca town, approximately $39 \mathrm{~m}$ from railway track No. 127 and 30 $\mathrm{m}$ from the road $\mathrm{I} / 11$,

Total equivalent sound pressure level A measured during night time 22:00 - 06:00:

$\mathrm{L}_{\text {Aeq }, 8 \mathrm{~h} \text { night }}=66.2 \mathrm{~dB} \ldots \quad$ overall noise - environment noise,

$\mathrm{L}_{\text {Aeq, } 8 \mathrm{~h} \text { night }}=65.3 \mathrm{~dB} \ldots \quad$ only noise from the railway line No. 127 ,

M5 - $2 \mathrm{~m}$ in front of the window of residential room on $2^{\text {nd }}$ floor of house No. 141, Svrčinovec settlement, approximately $240 \mathrm{~m}$ from railway track No. 127 and approximately $50 \mathrm{~m}$ from the road $\mathrm{I} / 11$,

Total equivalent sound pressure level A measured during night time 22:00 - 06:00:

$\mathrm{L}_{\text {Aeq }, 8 \mathrm{~h} \text { night }}=56.4 \mathrm{~dB} \ldots \quad$ overall noise - environment noise,

$\mathrm{L}_{\text {Aeq }, 8 \mathrm{~h} \text { night }}=55.4 \mathrm{~dB} \ldots \quad$ only noise from the railway line No. 127 ,

M6 - $2 \mathrm{~m}$ in front of the window of residential room on $2^{\text {nd }}$ floor of house No.835,

Svrčinovec settlement, approximately $43 \mathrm{~m}$ from railway track No. 127,

Total equivalent sound pressure level A measured during night time 22:00 - 06:00:

$\mathrm{L}_{\text {Aeq }, 8 \mathrm{~h} \text { night }}=68.4 \mathrm{~dB} \ldots \quad$ overall noise - environment noise,

$\mathrm{L}_{\text {Aeq }, 8 \mathrm{~h} \text { night }}=68.2 \mathrm{~dB} \ldots \quad$ only noise from the railway line No. 127 ,

M7 - $2 \mathrm{~m}$ in front of the window of residential room on $2^{\text {nd }}$ floor of house No. 354, Svrčinovec settlement, approximately $115 \mathrm{~m}$ from railway track No. 127 and approximately $300 \mathrm{~m}$ from the road $\mathrm{I} / 11$,

Total equivalent sound pressure level A measured during night time 22:00 - 06:00:

$\mathrm{L}_{\text {Aeq }, 8 \mathrm{~h} \text { night }}=46.7 \mathrm{~dB} \ldots \quad$ overall noise - environment noise,

$\mathrm{L}_{\text {Aeq } 8 \mathrm{~h} \text { night }}=44.6 \mathrm{~dB} \ldots \quad$ only noise from the railway line No. 127 ,

M8 - $2 \mathrm{~m}$ in front of the window of residential room on $2^{\text {nd }}$ floor of house No. 335, Svrčinovec settlement, approximately $160 \mathrm{~m}$ from railway track No. 127 and approximately $15 \mathrm{~m}$ from the road $\mathrm{I} / 11$,

Total equivalent sound pressure level A measured during night time 22:00 - 06:00:

$\mathrm{L}_{\text {Aeq, } 8 \mathrm{~h} \text { night }}=67.7 \mathrm{~dB} \ldots \quad$ overall noise - environment noise,

$\mathrm{L}_{\text {Aeq }, 8 \mathrm{~h} \text { night }}=61.9 \mathrm{~dB} \ldots \quad$ only noise from the railway line No. 127 ,

M9 - $2 \mathrm{~m}$ in front of the window of residential room on $1^{\text {st }}$ floor of house No. 490,

Svrčinovec settlement, approximately $100 \mathrm{~m}$ from railway track No. 127,

Total equivalent sound pressure level A measured during night time 22:00 - 06:00:

$\mathrm{L}_{\text {Aeq }, 8 \mathrm{~h} \text { night }}=56.2 \mathrm{~dB} \ldots \quad$ overall noise - environment noise,

$\mathrm{L}_{\text {Aeq, } 8 \mathrm{~h} \text { night }}=55.5 \mathrm{~dB} \ldots \quad$ only noise from the railway line No. 127 , 
M10 - 2m in front of the window of residential room on $3^{\text {th }}$ floor of house No. 882, Svrčinovec settlement, approximately $145 \mathrm{~m}$ from railway track No. 127,

Total equivalent sound pressure level A measured during night time 22:00 - 06:00:

$\mathrm{L}_{\text {Aeq }, 8 \mathrm{~h} \text { night }}=47.7 \mathrm{~dB} \ldots \quad$ overall noise - environment noise,

$\mathrm{L}_{\text {Aeq }, 8 \mathrm{~h} \text { night }}=47.2 \mathrm{~dB} \ldots \quad$ only noise from the railway line No. 127.

Tab.3 Evaluation of the measured and the calculated values [own research]

\begin{tabular}{|c|c|c|c|c|c|c|}
\hline \multicolumn{2}{|c|}{$\begin{array}{c}\text { Assessment point } \\
\text { (altitude from the } \\
\text { ground/ distance from } \\
\text { the rail. track) } \\
(\mathrm{m})\end{array}$} & $\begin{array}{c}\text { Land } \\
\text { category }\end{array}$ & PV & $\begin{array}{c}\text { Measured } \\
\text { values }(\mathrm{dB})\end{array}$ & $\begin{array}{c}\text { Assessed } \\
\text { measured value } \\
\mathrm{L}_{\mathrm{R}, \text { Aeq,n }} \\
(\mathrm{dB})\end{array}$ & $\begin{array}{c}\mathrm{L}_{\mathrm{R}, \text { Aeq,n }}-\mathrm{PH} \\
(\mathrm{dB})\end{array}$ \\
\hline M1 & $7^{\text {th }}$ floor $/ 145$ & II. & 45 & 60.1 & $61.9>45$ & 16.9 \\
\hline M2 & $2^{\text {nd }}$ floor $/ 60$ & III. & 55 & 59.6 & $61.4>55$ & 6.4 \\
\hline M3 & $1,5 / 300$ & II. & 45 & 48.6 & $50.4>45$ & 5.4 \\
\hline M4 & $2^{\text {nd }}$ floor $/ 39$ & III. & 55 & 65.3 & $67.1>55$ & 12.1 \\
\hline M5 & $2^{\text {nd }}$ floor $/ 240$ & II. & 45 & 55.4 & $57.2>45$ & 12.2 \\
\hline M6 & $2^{\text {nd }}$ floor $/ 43$ & III. & 55 & 68.2 & $70>55$ & 15.0 \\
\hline M7 & $2^{\text {nd }}$ floor $/ 115$ & II. & 45 & 44.6 & $46.4>45$ & 1.4 \\
\hline M8 & $2^{\text {nd }}$ floor $/ 160$ & II. & 45 & 61.9 & $63.7>45$ & 18.7 \\
\hline M9 & $1^{\text {st }}$ floor $/ 100$ & III. & 55 & 55.5 & $57.3>55$ & 2.3 \\
\hline M10 & $3^{\text {th }}$ floor $/ 145$ & II. & 45 & 47.2 & $49>45$ & 4.0 \\
\hline
\end{tabular}

\section{Conclusions}

In Tab. 3 all the measurement points are evaluated from the point of view of the territory category, it means the distance from the noise source and their compliance with the permissible values. The measurements were done before the modernization of the railway line. From the noise study it is clear that the following modernization of the railway line will require effective noise reduction measures. At all measuring points, the permissible noise values were exceeded for the night period. There is no visible effect of the distance from the noise source to the noise exposure level, because noise of the road and geographically rugged terrain also affected to the noise level.

Observance of nighttime noise level value for residential areas of category II. (45 dB) at the distance of $100 \mathrm{~m}$ to $200 \mathrm{~m}$ from the railroad is quite demanding. Compared with other countries (Fig. 2) it is clear that the Slovak republic belongs to the countries that have some of the highest permissible values in this area. 


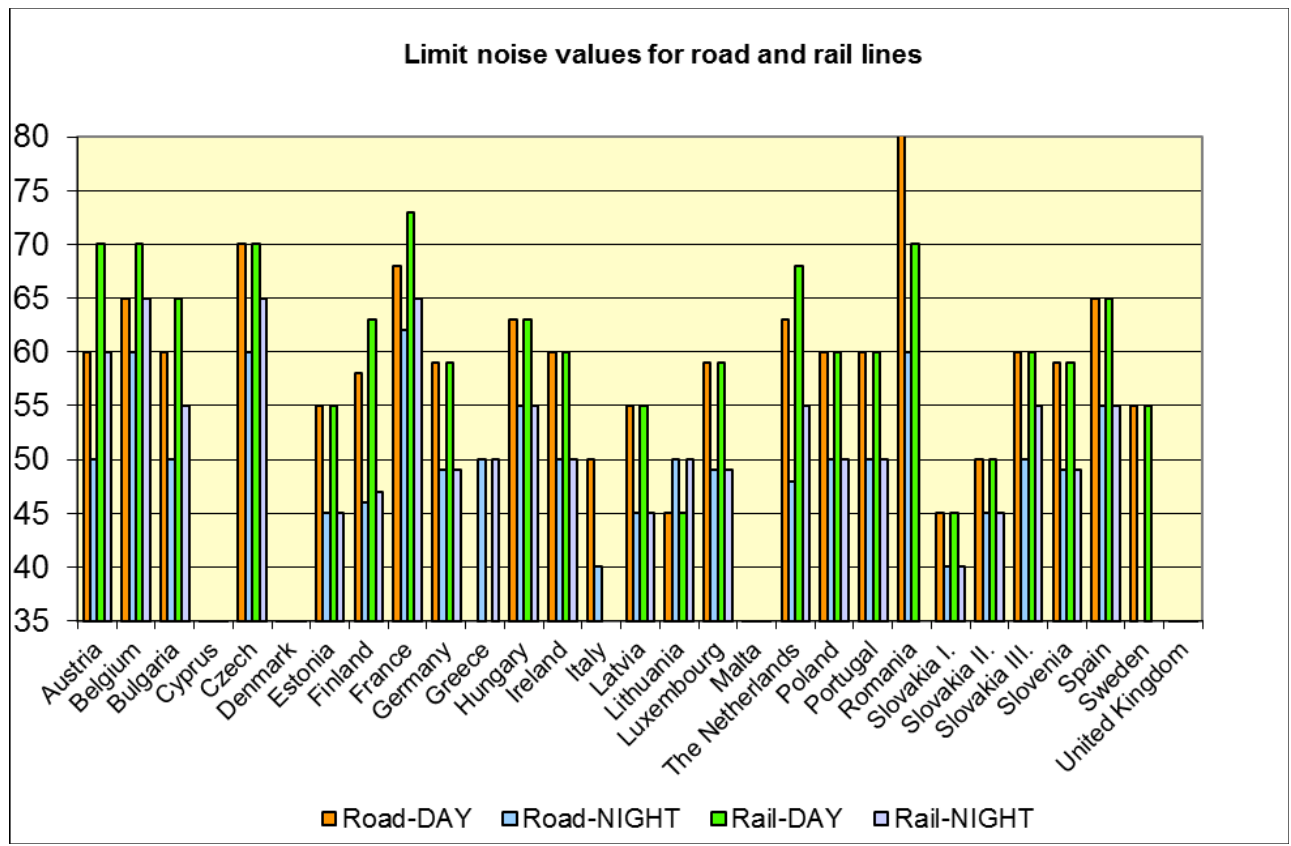

Fig. 2 Permissible noise levels for road and railway communications in EU countries from 2010 [8]

There are partial results of the grant VEGA 1/0766/15" Research of noise emissions sources in the railway transport and methods of their effective reduction" in the paper.

\section{References}

1. European Environment Agency, Noise in Europe 2014, EEA report 10. Luxembourg (Publications Office of the European Union 2014)

2. Murphy and King, (2014)

3. Decree of MZ No. 549/2007 Z.z. stating the details on the permissible levels of noise, infrasound and vibration and the requirements on objectification of noise, infrasound and vibration in the environment of $16^{\text {th }}$ August 2007 (2007)

4. STN EN ISO 3095 Railway applications. Acoustics. Measurement of noise emitted by railbound vehicles (2005)

5. Professional guidance: NRÚ/3116/2005 (2005)

6. J. Veverka, V. Kozel, L. Ládyš, M. Liberko, J. Chybík, Stavebni fyzika, (University of Technology Brno, 1998)

7. Archive of the ZPS Club in vibroacoustics, s.r.o. (2010)

8. M, Decký, A. Krokker, Hluk od cestnej dopravy ako limitujúci faktor kvality vonkajšieho prostredia. Fyzikálne faktory prostredia, 1, 205 (2011)

9. Grenčík, J., Skrúcaný, T., Volna, P.: Energy consumption as an important factor for decision on proper transport mode, In: TTS Technika transportu szynowego: koleje tramwaje - metro. - ISSN 1232-3829. - Vol 22, no. 12 (2015). 